\title{
The influence of Graves' orbitopathy treatment with intravenous glucocorticoids on adrenal function
}

\author{
Wpływ leczenia dożylnymi glukokortykosteroidami w orbitopatii Gravesa \\ na funkcję nadnerczy
}

\author{
Urszula Ambroziak, Gabriela Bluszcz, Tomasz Bednarczuk, Piotr Miśkiewicz \\ Department of Internal Medicine and Endocrinology, Medical University of Warsaw, Poland
}

\begin{abstract}
Introduction: Graves' orbitopathy (GO) is the commonest extrathyroidal feature of Graves' disease. For active, moderate to severe GO intravenous glucocorticoid pulse therapy (ivGCS) is the first-line treatment, which might be followed by oral glucocorticoid therapy. Glucocorticoid treatment, especially in the time of withdrawal, carries a risk of adrenal insufficiency. The aim of this study was to assess the pituitary-adrenal axis function in patients with GO before and at the cessation of ivGCS, and after further oral glucocorticoid therapy. Material and methods: Twenty patients received treatment in accordance with the EUGOGO protocol (500 mg methylprednisolone once a week for six weeks, then $250 \mathrm{mg}$ once a week for another six weeks) followed by oral prednisone at a gradually decreasing dose from $30 \mathrm{mg}$ /day over a three-month period. Adrenal function was evaluated directly before the ivGCS, before the last pulse, and after oral glucocorticoid intake. The assessment consisted of clinical evaluation, and measurements of morning total serum cortisol (TSC) and plasma adrenocorticotropic hormone (ACTH). Patients with decreased cortisol level underwent ACTH stimulation test with TSC measurements before, and 30 minutes and 60 minutes after the administration of synthetic ACTH.

Results: All patients before and at the cessation of ivGCS treatment demonstrated intact adrenal function. One patient after prednisone therapy presented decreased adrenal reserve. TSC concentration was significantly lower after the ivGCS $(p=0.025)$ and oral glucocorticoid therapy $(\mathrm{p}=0.0006)$ in comparison to evaluation before therapy.

Conclusions: Therapy with ivGCS for GO does not lead to secondary adrenocortical insufficiency. Further low-dose oral glucocorticoid therapy may result in secondary adrenocortical insufficiency in some patients. (Endokrynol Pol 2017; 68 (4): 430-433)

Key words: glucocorticoids; methylprednisolone; Graves' orbitopathy; adrenal insufficiency; cortisol

\section{Streszczenie}

Wstęp: Orbitopatia Gravesa (GO) to najczęstsza pozatarczycowa manifestacja choroby Gravesa i Basedowa. W aktywnej, umiarkowanej do ciężkiej postaci GO leczeniem pierwszego rzutu są dożylne pulsy glukokortykosteroidów (ivGCS), które mogą być uzupełnione o doustną sterydoterapię. Sterydoterapia, a zwłaszcza jej przerwanie, niesie za sobą ryzyko rozwoju wtórnej niedoczynności kory nadnerczy. Celem niniejszej pracy jest ocena funkcji osi podwzgórze-przysadka-nadnercza u pacjentów leczonych z powodu GO: przed rozpoczęciem leczenia dożylnym sterydami, w momencie jego zakończenia oraz po podtrzymującej doustnej sterydoterapii.

Materiał i metody: Badaniem objęto dwudziestu pacjentów leczonych zgodnie z protokołem EUGOGO (bolus dożylny 500 mg metyloprednizolonu raz w tygodniu przez 6 tygodni, następnie $250 \mathrm{mg}$ raz w tygodniu przez kolejne 6 tygodni) oraz prednizonem w redukowanych dawkach od $30 \mathrm{mg} / \mathrm{d}$ przez kolejne 3 miesiące. Badanie funkcji nadnerczy miało miejsce przed rozpoczęciem leczenia, przed otrzymaniem ostatniego pulsu oraz po zakończeniu doustnej sterydoterapii. Ocena obejmował ocenę kliniczną, pomiar stężenia w surowicy porannego kortyzolu (TSC) oraz hormonu adrenokortykotropowego (ACTH). U pacjentów, u których stwierdzono obniżone stężenie TSC, wykonywano test stymulacji ACTH z pomiarem stężenia kortyzolu w surowicy przed podaniem oraz w $30^{\prime} \mathrm{i}$ w $60^{\prime}$ minucie po podaniu syntetycznego ACTH. Wyniki: Przed rozpoczęciem oraz w momencie zakończenia leczenia dożylnego sterydami wszyscy pacjenci mieli zachowaną prawidłową funkcję kory nadnerczy. Po zakończeniu leczenia doustnymi sterydami u jednego pacjenta stwierdzono obniżenie rezerwy nadnerczowej. TSC było istotnie niższe przy zakończeniu ivGCS $(\mathrm{p}=0,025)$ oraz po zakończeniu leczenia prednizonem $(\mathrm{p}=0,0006) \mathrm{w}$ porównaniu z wyjściowym badaniem.

Wnioski: Dożylna sterydoterapia w pulsach w leczeniu GO nie prowadzi do wtórnej niedoczynności kory nadnerczy. Następcze leczenie doustnymi sterydami może powodować wtórną niedoczynność kory nadnerczy u niektórych pacjentów. (Endokrynol Pol 2017; 68 (4): 430-433)

Słowa kluczowe: glukokortykosteroidy; metyloprednizolon; orbitopatia Gravesa; niedoczynność kory nadnerczy; kortyzol
\end{abstract}

\section{Introduction}

Graves' orbitopathy (GO) is the commonest and most important extrathyroidal manifestation of Graves' disease $[1,2]$. Active, moderate to severe GO represents about $5 \%$ of cases $[3,4]$. Intravenous glucocorticoid pulse therapy (ivGCS) is the first-line treatment in this group of patients [2]. After cessation of methylprednisolone (MP) treatment, low-dose oral therapy with prednisone might be considered [5]. Treatment with 
supraphysiological doses of glucocorticoids carries a risk of numerous side effects, of which suppression of hypothalamic-pituitary-adrenal (HPA) axis is particularly dangerous and may precipitate adrenal crisis [6]. Some surveys show that the frequency of acute adrenocortical insufficiency might be greater than expected [7]. The purpose of this study was to assess the HPA-axis function in patients with GO before, at the cessation of ivGCS, and after the further oral therapy with prednisone.

\section{Material and methods}

\section{Patients}

Twenty consecutive patients (14 females) with active, moderate to severe GO, with an average age of 51.5 years (range 24-74 years), treated with ivGCS and subsequently prednisone, were included to the study. All the patients were assessed according to European Group on Graves' Orbitopathy (EUGOGO) criteria, and all were euthyroid at initiation of treatment. Patients under glucocorticoid therapy and medication influencing cortisol-binding protein serum level in the last six months were excluded from the study.

\section{Treatment schedule}

The patients received treatment at the Department of Endocrinology, Medical University of Warsaw between 2012 and 2016. The therapy included administration of intravenous (IV) pulses of MP in accordance with the EUGOGO protocol (500 mg MP once a week for six weeks, then $250 \mathrm{mg}$ once a week for another six weeks - cumulative dose $4.5 \mathrm{~g}$ ). Once the initial treatment was finished, patients received oral prednisone at a gradually reduced daily morning dose from $30 \mathrm{mg} /$ day to $5 \mathrm{mg} /$ day over a three-month period. This was followed by oral substitution of hydrocortisone (HCT) $10 \mathrm{mg}$ /day until the day of the next examination (mean 23 days of HCT intake). Time points for adrenal function assessment were: i) directly before the beginning of treatment ( $1^{\text {st }}$ pulse), ii) directly before the last pulse of MP (12 $2^{\text {th }}$ pulse), and iii) after cessation of prednisone therapy. The evaluation of HPA-axis function was performed by measurements of morning total serum cortisol (TSC) and plasma adrenocorticotropic hormone (ACTH). We ruled out adrenal insufficiency if the patient fulfilled two criteria simultaneously: lack of clinical features of adrenal insufficiency (weakness, fatigue, orthostatic hypotension, muscle pain, hyperpigmentation, nausea, weight loss, hypoglycaemia) and value of morning TSC $\geq 10 \mu \mathrm{g} / \mathrm{dL}$. Patients who did not fulfill these criteria underwent an ACTH stimulation test (250 $\mu \mathrm{g}$ Synacthen $\left.{ }^{\circledR}\right)$ with TSC measurements before, 30 minutes and 60 minutes after the administration of intramuscular bolus of synthetic ACTH. The criterion of intact HPA-axis function was defined as stimulated serum cortisol concentration of $\geq 18 \mu \mathrm{g} / \mathrm{dL}$ [6].

\section{Laboratory evaluation}

Cortisol and ACTH concentrations were measured using ECLIA Cobas ${ }^{\circledR}$ diagnostic kits (Roche Diagnostics Limited, Burgess Hill, UK). The immunoassay for the in vitro quantitative determination of ACTH in human EDTA plasma has a measuring range of $1.00-2000 \mathrm{pg} / \mathrm{mL}$, the inter assay coefficient of variation is maximal $2.7 \%$, the intra assay coefficient of variation is maximal $5.4 \%$, and the detection limit is $1.00 \mathrm{pg} / \mathrm{mL}$. The immunoassay for the in vitro quantitative determination of cortisol in human serum, plasma, urine, and saliva has a measuring range of $0.018-63.4 \mu \mathrm{g} / \mathrm{dL}$, the inter assay coefficient of variation is maximal $1.7 \%$, the intra assay coefficient of variation is maximal $2.8 \%$, and the detection limit is $0.018 \mu \mathrm{g} / \mathrm{dL}$. ACTH stimulation test was performed with synthetic ACTH $\left(0.25 \mathrm{mg}\right.$ Synacthen ${ }^{\circledR}$ Novartis, Basel, Switzerland).

\section{Statistical analysis}

Results are expressed as means with range for parametric data, and as median with range for nonparametric data. Parametric data were analysed using paired $t$ test and nonparametric data using Wilcoxon signed rank test. Statistical significance was assumed when a null hypothesis could be rejected at $P<0.05$. Statistical analyses were performed using software STATISTICA ver. 10.0.

\section{Results}

Before and at cessation of ivGCS all 20 patients fulfilled all the criteria (laboratory and clinical) of sufficient adrenal function (Fig. 1). After further three months of prednisone treatment while on HCT substitution, one patient presented decreased adrenal reserve (cortisol in ACTH stimulation test was $0^{\prime}: 1.46 \mu \mathrm{g} / \mathrm{dL}$; $\left.30^{\prime}: 10.51 \mu \mathrm{g} / \mathrm{dl} ; 60^{\prime}: 15.57 \mu \mathrm{g} / \mathrm{dL}\right)$. Mean morning TSC concentration was $18.4 \mu \mathrm{g} / \mathrm{dL}$ (9.2-27.3), $14.9 \mu \mathrm{g} / \mathrm{dl}$ (5.3-29.7), and $13.1 \mu \mathrm{g} / \mathrm{dl}$ (6.9-18.8) before treatment, at the cessation of ivGCS, and after oral prednisone therapy, respectively. The decrease of TSC level before the treatment and after the MP therapy, as well as before the treatment and after the oral prednisone therapy, was statistically significant ( $p<0.05$ ) (Fig. 2). Median ACTH concentrations were $13.3 \mathrm{pg} / \mathrm{mL}$ (2.9-62.1), $10.3 \mathrm{pg} / \mathrm{ml}$ (3.1-63.3), and $12.2 \mathrm{pg} / \mathrm{ml}(2.5-28.8)$ before the treatment, after the ivGCS, and after the oral prednisone therapy, respectively (Fig. 3). The difference between plasma ACTH during the treatment was not statistically significant. 


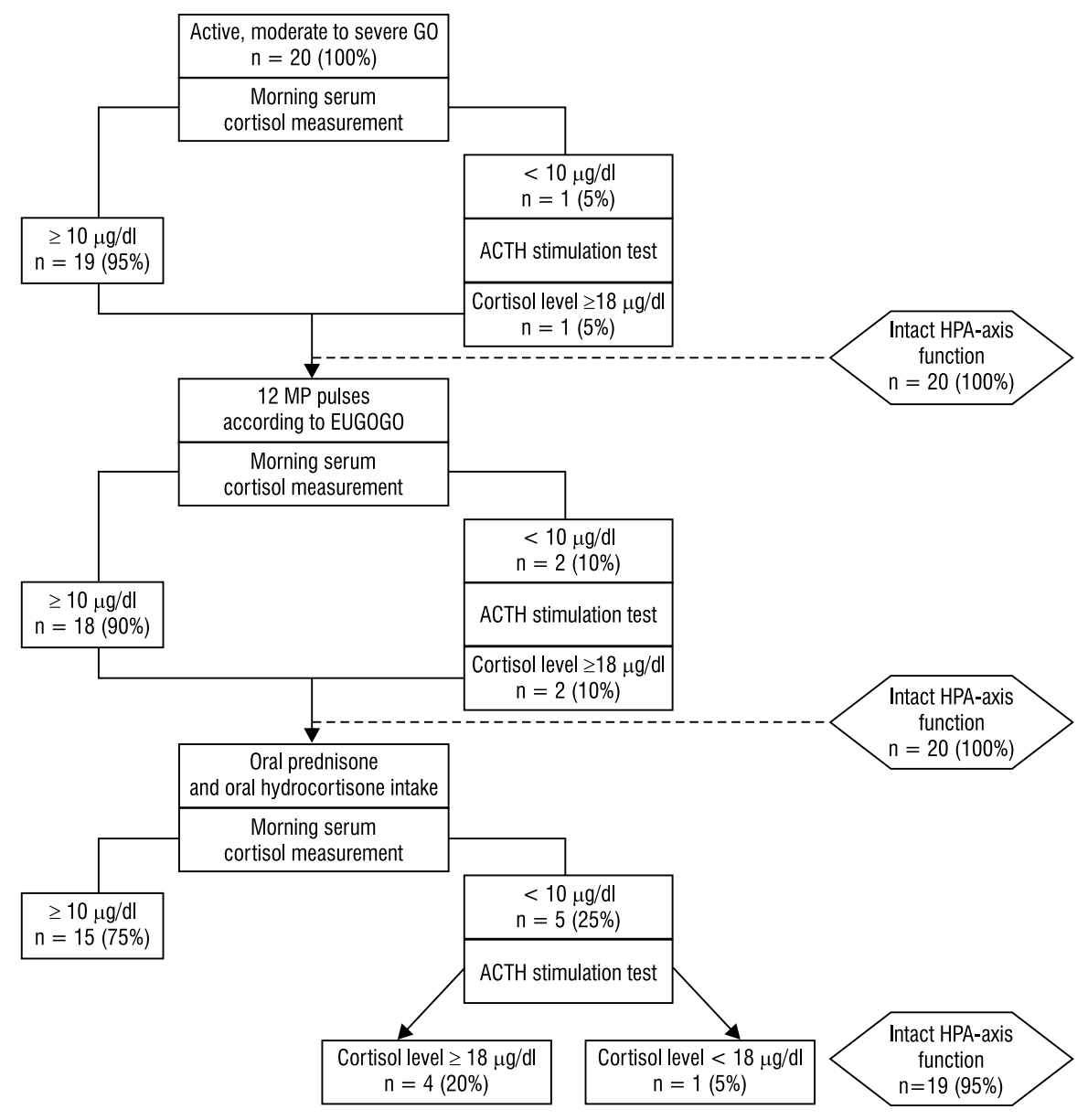

Figure 1. Schedule of treatment. Outcome in three time points

Rycina 1. Schemat leczenia. Analiza wyników w trzech punktach czasowych

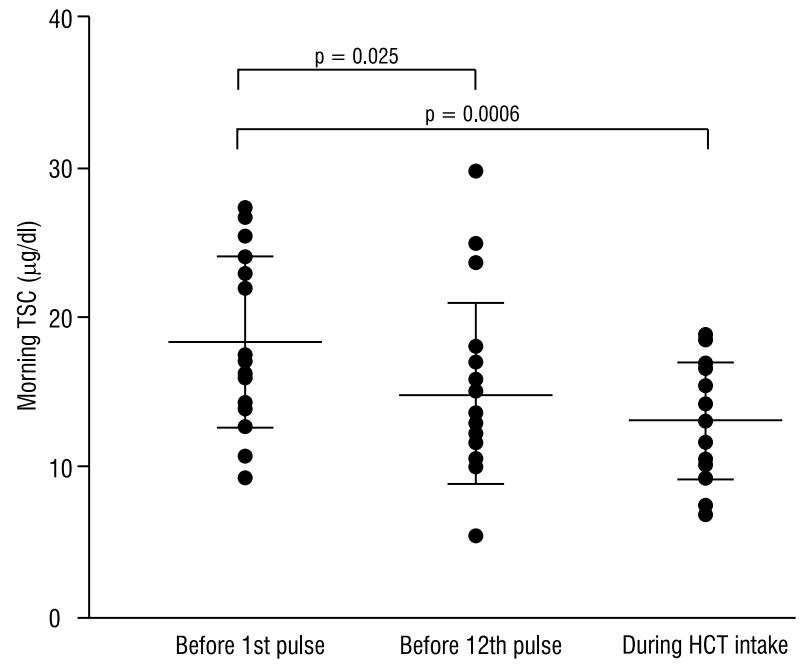

Figure 2. Morning total serum cortisol level in all patients in three time points. Diagram shows the mean value (long cross line) with standard deviation (shorter cross lines). Bullets represent individual cortisol levels. TSC - total serum cortisol

Rycina 2. Poranne stężenia kortyzolu u wszystkich pacjentów w trzech punktach czasowych. Na diagramie umieszczono średniq wartość (dtuga linia poprzeczna) z odchyleniem standardowym (krótkie linie poprzeczne). Kropki oznaczają stężenia kortyzolu u poszczególnych pacjentów. TSC — poranne stężenie kortyzolu

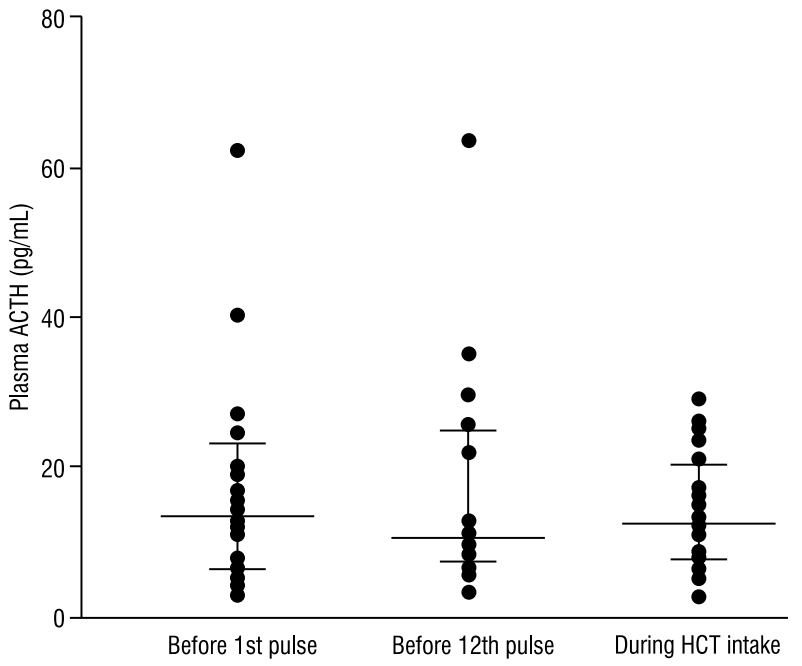

Figure 3. Plasma ACTH level in all patients in three time points. Diagram shows the median value (long cross line) with interquartile range (shorter cross lines). Bullets represent individual ACTH levels

Rycina 3. Stężenie ACTH w osoczu u wszystkich pacjentów w trzech punktach czasowych. Na diagramie umieszczono wartość mediany (dtuga linia poprzeczna) z rozstępem międzykwartylowym (krótkie linie poprzeczne). Kropki oznaczaja stężenia ACTH u badanych pacjentów 


\section{Discussion}

Secondary adrenal insufficiency (AI) occurs in up to $100 \%$ of patients treated with oral glucocorticoids [4]. However, inhaled GCS may cause AI as well [7, 8]. Data about the influence of intravenous glucocorticoids used in the treatment of GO on the HPA-axis are scarce. Greek and Danish studies showed no association between ivGCS treatment and AI development $[9,10]$. In our study the same conclusion was drawn. The cause of the lack of persistent HPA-axis suppression may be a result of periodic administration and transient suppression, which results in HPA-axis recovery. However, a statistically lower morning TSC after cessation of pulses was observed. It suggests that greater doses of IV MP (e.g. treatment of $\mathrm{GO}$ with higher cumulative doses than $4.5 \mathrm{~g}$ ) might cause HPA-axis suppression. This requires further evaluation in patients treated with higher doses of MP or in different schedule (e.g. therapy of dysthyroid optic neuropathy).

Factors that may increase AI risk after GCS withdrawal are well defined [11]. Patients on long-acting GCS equal to oral prednisone in dose $\geq 20 \mathrm{mg}$ per day for at least three weeks, evening dose $\geq 5 \mathrm{mg}$, and cushingoid features may predispose to AI. We have also analysed in our group the HPA status after three months of treatment with oral prednisone. Interestingly one patient developed AI at this point of therapy. Other GCS side effects occur also less frequently after IV compared to oral route, which may be a result of the specific action of high GCS doses [12]. Buttgereit et al. postulated three "modules" of glucocorticoid effect on cells resulting from different concentrations: i) low concentrations mediate effects via genomic events, ii) medium concentrations bind to cell surface receptors, which activate cross membrane signal transmission for genomic and non-genomic intracellular events, and iii) at very large concentrations steroids dissolve in the cell membrane resulting in greater membrane stability and reduced non-genomic cell function $[13,14]$.

A possible limitation of the study is that we ruled out adrenal insufficiency if the patient fulfilled two criteria simultaneously: lack of clinical symptoms of adrenal insufficiency, which we believe is the strongest indicator of adrenal insufficiency, and morning cortisol $>10 \mu \mathrm{g} / \mathrm{dL}$. A stimulation test with Synacthen was performed in all patients with cortisol $\leq 10 \mu \mathrm{g} / \mathrm{dL}$ and/or clinical symptoms of adrenal insufficiency. Our decision about the study design and serum morning cortisol cut-off set at $10 \mu \mathrm{g} / \mathrm{dL}$ was, however, based on the literature [15], previous studies [16-18], and our experience supported by assessment of clinical status.

\section{Conclusions}

Intravenous pulse treatment for $\mathrm{GO}$, with cumulative dose of $4.5 \mathrm{gMP}$, does not lead to secondary adrenocortical insufficiency. Further low-dose oral prednisone therapy can result in secondary adrenocortical insufficiency in some patients.

\section{Acknowledgment}

The study protocol was approved by the Commission of Bioethics at the Medical University of Warsaw, Poland.

\section{References}

1. Bahn RS, Heufelder AE. Pathogenesis of Graves' ophthalmopathy. N Engl J Med. 1993; 329(20): 1468-1475, doi: 10.1056/ NEJM199311113292007, indexed in Pubmed: 8413459.

2. Bartalena L, Baldeschi L, Boboridis K, et al. European Group on Graves Orbitopathy (EUGOGO). The 2016 European Thyroid Association/ European Group on Graves' Orbitopathy Guidelines for the Management of Graves' Orbitopathy. Eur Thyroid J. 2016; 5(1): 9-26, doi: 10.1159/000443828, indexed in Pubmed: 27099835.

3. Laurberg P, Berman DC, Bülow Pedersen I, et al. Incidence and clinica presentation of moderate to severe graves' orbitopathy in a Danish population before and after iodine fortification of salt. J Clin Endocrinol Metab. 2012; 97(7): 2325-2332, doi: 10.1210/jc.2012-1275, indexed in Pubmed: 22518849 .

4. Tanda ML, Piantanida E, Liparulo L, et al. Prevalence and natura history of Graves' orbitopathy in a large series of patients with newly diagnosed graves' hyperthyroidism seen at a single center. J Clin Endocrinol Metab. 2013; 98(4): 1443-1449, doi: 10.1210/jc.2012-3873, indexed in Pubmed: 23408569.

5. Bednarczuk T, Bar-Andziak E, Hubalewska-Dydejczyk A, et al. [Management of Graves' orbitopathy. Comments on the EUGOGO consensus statement]. Endokrynol Pol. 2009; 60(4): 312-330, indexed in Pubmed 19753546.

6. Dinsen S, Baslund Bo, Klose M, et al. Why glucocorticoid withdrawal may sometimes be as dangerous as the treatment itself. Eur J Intern Med. 2013; 24(8): 714-720, doi: 10.1016/j.ejim.2013.05.014, indexed in Pubmed: 23806261.

7. Todd GRG, Acerini CL, Ross-Russell R, et al. Survey of adrenal crisis associated with inhaled corticosteroids in the United Kingdom. Arch Dis Child. 2002; 87(6): 457-461, indexed in Pubmed: 12456538.

8. Zöllner EW, Lombard CJ, Galal U, et al. Hypothalamic-pituitary-adrenal axis suppression in asthmatic school children. Pediatrics. 2012; 130(6): e1512-e1519, doi: 10.1542/peds.2012-1147, indexed in Pubmed: 23147980.

9. Giotaki Z, Fountas A, Tsirouki T, et al. Adrenal reserve following treatment of Graves' orbitopathy with intravenous glucocorticoids. Thyroid. 2015; 25(4): 462-463, doi: 10.1089/thy.2014.0533, indexed in Pubmed: 25602127.

10. Jespersen S, Nygaard B, Kristensen LØ. Methylprednisolone Pulse Treatment of Graves' Ophthalmopathy Is Not Associated with Secondary Adrenocortical Insufficiency. Eur Thyroid J. 2015; 4(4): 222-225, doi: 10.1159/000440834, indexed in Pubmed: 26835424.

11. Furst DE, Saag KG. Glucocorticoid withdrawal. In: Post TW. UpToDate, Waltham, MA 2016

12. Miśkiewicz P Kryczka A, Ambroziak $U$, et al. Is high dose intravenous methylprednisolone pulse therapy in patients with Graves' orbitopathy safe? Endokrynol Pol. 2014; 65(5): 402-413, doi: 10.5603/EP.2014.0056, indexed in Pubmed: 25301492.

13. Buttgereit F, Saag KG, Cutolo M, et al. The molecular basis for the effectiveness, toxicity, and resistance to glucocorticoids: focus on the treatment of rheumatoid arthritis. Scand J Rheumatol. 2005; 34(1): 14-21, doi: 10.1080/03009740510017706, indexed in Pubmed: 15903020.

14. Gupta G, Jain A, Narayanasetty N. Steroid pulse therapies in dermatology. Muller Journal of Medical Sciences and Research. 2014; 5(2): 155, doi: 10.4103/0975-9727.135756.

15. Willenberg HS, Bornstein SR. Adrenal Insufficiency. In: Lang F, eds. Encyclopedia of Molecular Mechanisms of Disease. Springer-Verlag GmbH Berlin, Heidelberg. ; 2009: 41-44, doi: 10.1007/978-3-540-29676-8.

16. Hägg E, Asplund K, Lithner F. Value of basal plasma cortisol assays in the assessment of pituitary-adrenal insufficiency. Clin Endocrinol (Oxf). 1987; 26(2): 221-226, doi: 10.1111/j.1365-2265.1987.tb00780.x, indexed in Pubmed: 3311477.

17. Khan MI, Habra MA, McCutcheon IE, et al. Random postoperative day-3 cortisol concentration as a predictor of hypothalamic-pituitary-adrenal axis integrity after transsphenoidal surgery. Endocr Pract. 2011; 17(5): 717-726, doi: 10.4158/EP11013.OR, indexed in Pubmed: 21454228.

18. Mitchell J, Barbosa G, Tsinberg M, et al. Unrecognized adrenal insufficiency in patients undergoing laparoscopic adrenalectomy. Surg Endosc. 2009; 23(2): 248-254, doi: 10.1007/s00464-008-0189-1, indexed in Pubmed: 19037697. 